\title{
Albumin and multiple sclerosis
}

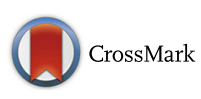

\author{
Steven M. LeVine
}

\begin{abstract}
Leakage of the blood-brain barrier (BBB) is a common pathological feature in multiple sclerosis (MS). Following a breach of the BBB, albumin, the most abundant protein in plasma, gains access to CNS tissue where it is exposed to an inflammatory milieu and tissue damage, e.g., demyelination. Once in the CNS, albumin can participate in protective mechanisms. For example, due to its high concentration and molecular properties, albumin becomes a target for oxidation and nitration reactions. Furthermore, albumin binds metals and heme thereby limiting their ability to produce reactive oxygen and reactive nitrogen species. Albumin also has the potential to worsen disease. Similar to pathogenic processes that occur during epilepsy, extravasated albumin could induce the expression of proinflammatory cytokines and affect the ability of astrocytes to maintain potassium homeostasis thereby possibly making neurons more vulnerable to glutamate exicitotoxicity, which is thought to be a pathogenic mechanism in MS. The albumin quotient, albumin in cerebrospinal fluid (CSF)/albumin in serum, is used as a measure of bloodCSF barrier dysfunction in MS, but it may be inaccurate since albumin levels in the CSF can be influenced by multiple factors including: 1) albumin becomes proteolytically cleaved during disease, 2) extravasated albumin is taken up by macrophages, microglia, and astrocytes, and 3) the location of BBB damage affects the entry of extravasated albumin into ventricular CSF. A discussion of the roles that albumin performs during MS is put forth.
\end{abstract}

Keywords: Albumin, Albumin quotient, Blood-brain barrier, Cerebrospinal fluid, Experimental autoimmune encephalomyelitis, Macrophages, Multiple sclerosis, Reactive nitrogen species, Reactive oxygen species

\section{Background}

Multiple sclerosis (MS) is believed to result from an underlying autoimmune mechanism that leads to the development of central nervous system (CNS) lesions that eventually cause sensory and motor symptoms [1, 2]. The majority of patients experience a relapsing remitting type of MS (RRMS), but over time the condition frequently transitions into a progressive form of disease $[1,2]$. Active demyelinating lesions can result from proinflammatory immune cells migrating across the vasculature into the CNS, and this process is affiliated with a breakdown of the blood-brain barrier (BBB) [3-5]. Besides this association with immune cells, BBB leakage can result in the extravasation of plasma components that cross damaged vessels and enter the CNS. Perivascular immune cells and vascular leakage occur in both acute and chronic MS lesions [6], and damage to the $\mathrm{BBB}$ may be relatively persistent since vascular changes can be present without concurrent inflammatory cells,

Correspondence: slevine@kumc.edu Department of Molecular and Integrative Physiology, University of Kansas Medical Center, Kansas City, KS, USA 
protective and pathogenic mechanisms of albumin relative to MS.

\section{Review}

A compromised BBB is a common occurrence in MS

MRI detection of gadolinium (Gd) enhancing lesions is one measure used for the diagnosis of MS and for monitoring disease activity $[16,17]$. Gd does not enter the brain when there is an intact $\mathrm{BBB}$, but when there is a breach in the BBB, it appears as a local enhancement. Gd-enhancing lesions occur most commonly in RRMS and secondary progressive MS (SPMS), but can also occur in benign MS, clinically isolated syndrome, pediatric MS, and primary progressive MS (PPMS) (more commonly, enhancing lesions occur earlier in the course of PPMS), and enhancements are usually considered a marker of active lesions [18-23]. Lesions can have different appearances, with nodular or uniform Gd enhancements representing new lesions associated with $\mathrm{BBB}$ leakage while ring or arc enhancements suggest older lesions [24, 25]. Based on numerous Gd studies, the breakdown of the $\mathrm{BBB}$ is relatively common occurrence during MS, and a triple dose of Gd may increase the ability to detect lesions $[18,19,26]$ with one study revealing an average of 5.17 (median 3.38) enhancing lesions per month per patient (37 RRMS, 3 SPMS) with an average of 3.37 (median 2.5) of the lesions being new enhancements per month per patient when using a delay of 20 min for imaging after the administration of a triple dose of Gd [27].

\section{BBB damage in MS results in excess albumin gaining access to the CNS}

BBB leakage results in the extravasation of leukocytes, some red blood cells (RBCs), and plasma proteins into the CNS in both experimental autoimmune encephalomyelitis (EAE) [28-31], an animal model of MS, and MS tissue [32-35]. Since albumin is the predominant protein in plasma, it would be expected to be among the proteins that gain access to the CNS. For instance, proteomic [30, 36], immunohistochemical [37-40], immunoblotting [41], Evan's blue labeled albumin [42], CSF [43, 44], and radiolabeled albumin [45] studies in EAE subjects revealed that albumin enters the CNS during disease. Albumin extravasation precedes both cellular inflammation and clinical signs, and it occurs initially around vessels, i.e., perivascular space in subpia, and then spreads diffusely into the CNS [38].

In human MS tissue, albumin was found widely dispersed in the CNS in immunohistochemical studies of mostly chronic MS cases [46] and inactive plaques [7], and it was revealed by proteomics studies in some chronic plaques/lesions [35, 47]. It is somewhat surprising that albumin has not been detected or described more frequently in active MS plaques, especially since a low dose of gadofosveset trisodium, a Gd compound that binds albumin reversibly, revealed more enhancements, albeit at a $4 \mathrm{~h}$ time point, compared to gadoterate meglumine (only $<4 \%$ is bound to plasma proteins in vitro [48]), at a more standard 4 min time point [49]. Some possible reasons why albumin has not been detected or described more frequently in active plaques are as follows. In contrast to fibrinogen, which is more discretely localized around leaky vessels and readily detected in active plaques $[46,50,51]$, the distribution of albumin appears to be more widespread following BBB leakage $[7,40,46]$ which could make it more difficult to detect by immunohistochemistry. Additionally, albumin appears to be cleared relatively quickly from the CNS following extravasation [40]. Albumin that was labeled with gold, for detection via electron microscopy, has been shown to be rapidly taken up by subarachnoidal macrophages [52], which is relevant since macrophages are a substantial component of active lesions, but less so in inactive plaques [53-55], which interestingly have more detectable albumin [7]. Albumin is also proteolytically cleaved during acute phases of RRMS [56], which could make it more difficult to detect by immunohistochemistry.

CSF albumin levels or the albumin quotient (albumin in CSF/albumin in serum) were elevated in 12-23\% of MS cases [57-62]. An elevated level of albumin in the CSF, or an elevated albumin quotient, is thought to be a measure of blood-CSF dysfunction in MS [63], and it has been used as an indicator of BBB permeability $[58,60,62]$. The albumin quotient is less sensitive than Gd MRI for detecting BBB disruption especially in supraspinal lesions [64], and the albumin quotient is sensitive to the subject's age [65].

Detection of an elevation of albumin in CSF would be expected to be dependent on the timing and location of $\mathrm{BBB}$ leakage. Albumin rapidly diffuses through the rat brain with a disappearance half-life of $\sim 12 \mathrm{~h}$ [66]. After infusion into the caudate nucleus of the rat, only a relatively small percentage of the infused albumin ended up in the CSF at the cisterna magna [66] indicating that albumin can exit the CNS by a route(s) other than through the ventricular system $[64,66]$. Indeed, following an intracerebral injection of ovalbumin in mice, some digestion products found their way to the cervical lymph node [67]. Although caution about extrapolation of these results is warranted, since ovalbumin is antigenically different than mouse albumin, ovalbumin products were observed in the lymph node at 2,4 , and $8 \mathrm{~h}$, and 7 days, following an intracerebral injection [67]. A small percentage of the digestion products remained in the CNS, i.e., in $\mathrm{CD} 11 \mathrm{~B} / \mathrm{MAC}-1^{+}$cells (monocytes), over long periods, e.g., 4 weeks after injection, but 
these were largely present around the injection site [67]. In addition to different exit routes, it is likely that a change in CSF albumin levels during MS is sensitive to the location of the BBB leakage with spinal lesions and possibly circumventricular lesions potentially giving rise to the greatest elevation [64]. It is also relevant to note that CSF albumin levels are dependent on the rate of albumin influx from multiple sources (e.g., transport from blood to CSF in the choroid plexus, BBB leakage, and possibly synthesis within the CNS) as well as the rate of efflux (e.g., turnover or flow of CSF). In normal individuals, the major source of CSF albumin is its transport from the blood, via binding glycoprotein receptors on epithelial cells in the choroid plexus, and subsequent transfer into the ventricular CSF [68]. In MS, changes in albumin transfer through the choroid plexus, BBB leakage, and an increased CNS synthesis of albumin could all affect the CSF albumin concentration.

The volume of CSF is renewed rapidly in the 3 month (11 times/day) and 19 month (10.8 times/day) rat, and more slowly in the 30 month rat (3 times/day) [69]. In the human, CSF is renewed $\sim 4$ times/day [69]. The clearance of albumin in the CSF is relatively fast, e.g., in the mouse, albumin administered to the CSF resulted in its rapid clearance, e.g., only $\sim 6 \%$ remained in the CSF at $1 \mathrm{~h}$ [70]. During disease, the rate of albumin turnover/clearance could be altered. The rate of CSF flow through the aqueduct of Sylvius is decreased in MS patients [71], and a decreased flow could alter albumin concentrations [72], e.g., if the rate of albumin influx was constant but flow decreased, then the albumin concentration could increase.

Additionally, albumin catabolism could affect its concentration in CSF. Albumin is rapidly sequestered by subarachnoidal macrophages [52] and it can be taken up by astrocytes, microglia and neurons [73-76]. Furthermore, albumin fragments were found in the CSF of RRMS subjects during an acute phase, and these were differentially observed compared to CSF from control and Leber hereditary optic neuropathy subjects [56]. It has been suggested that albumin fragmentation is due to protease action by infiltrating immune cells [56]. Cytotoxic lymphocytes and macrophages produce proteases $[77,78]$, that in theory could act on albumin [56], but albumin fragmentation has been observed in the CSF from hydrocephalus [79], which results in a different inflammatory profile than MS. Data from a study on bronchoalveolar lavage fluid suggested that matrix metalloproteinase 3 (MMP-3) was responsible for digesting albumin, although other proteases may have also been involved in the fragmentation [80]. MMP-3 plasma levels are elevated in MS compared to control subjects [81] and MMP-3 levels in serum are increased during a relapse compared to remission [82]. MMP-3 is produced by a variety of CNS cells, e.g., microglia/macrophages, pericytes, astrocytes, endothelial cells, and ischemic neurons [8385], and in MS MMP-3 expression has been observed in microglia/macrophages, astrocytes, and microvessels [86]. It is likely that multiple proteases act on albumin during MS, but independent of the cause of albumin fragmentation, the detection of albumin in CSF (or serum) by electrophoresis could miss these fragments resulting in an underrepresentation of the amount of albumin in CSF from MS subjects. Thus, albumin levels might be elevated in a greater percentage of MS patients if fragmented albumin was detected by the assay.

Given that multiple factors can influence CSF albumin levels, an assay measuring CSF albumin levels would be expected to be an imprecise way to assess BBB leakage, or blood-CSF dysfunction, in MS. A summary of influencing factors include: BBB damage can occur anywhere in the CNS and the location of BBB leakage can affect the entry of albumin into the ventricular system; the rate of albumin or CSF transport or production may be altered during disease; albumin leaked into the CNS can exit by means other than into the ventricular system; the timing of CSF collection may not exactly coincide with the maximal peak of BBB leakage; extravasated albumin can be catabolized by immune or CNS cells; and the assay likely misses albumin that has been digested. Thus, the determination that $\sim 12-23 \%$ of MS cases have an elevated CSF albumin or albumin quotient, and therefore a leaky BBB [57-62], could be inaccurate. If the albumin quotient is flawed, then this has the potential to impact the CSF IgG index, which is a commonly used as a measure of IgG production within the CNS, since the index represents the ratio of CSF IgG to CSF albumin divided by the ratio of serum IgG to serum albumin. However, at present there is little data that directly addresses whether the albumin quotient or IgG index are influenced by the factors listed above, and if they are influenced, it is possible that the impact would not be sufficient to affect these measures in a substantial manner. Thus, additional studies are needed to resolve this potential issue.

In RRMS, there was a trend between decreased CSF flow and relapse rate in the preceding year [71], and an elevated albumin quotient at the time of a first clinical event, thought to be related to MS, is associated with a greater reduction in volume of several brain structures within 2 years of the clinical event [62]. This raises the possibility that the inflammation accounting for this elevation in CSF albumin (or reduced CSF flow), or the leaked albumin or other plasma component entering the brain, caused more severe pathological changes. 


\section{Protective roles of albumin during MS}

Numerous studies have established that reactive oxygen species (ROS) and reactive nitrogen species (RNS) are participants in EAE and MS pathogenesis. Elevation of markers of ROS and RNS presence have been observed in leukocytes, serum, CSF, and CNS tissue of EAE and MS subjects [40, 87-99]. Given the high concentration of albumin in plasma, and the leakage of the BBB that occurs during disease, albumin would be expected to be an abundant substrate for ROS and RNS in MS. Thus, albumin could have a protective effect on the disease course by acting as a target for reactive molecules that otherwise would have greater access to damage more important biomolecules.

Serum albumin has anti-oxidant properties, in particular, Cys34 (which is conserved among mammals) scavenges free radicals, and six methionine residues can become oxidized $[15,100]$. Besides oxidation, human serum albumin is a recipient of nitration and nitrosylation reactions [15, 100-102], and S-nitrosylated human serum albumin can serve as a transport mechanism for nitric oxide [103, 104]. Since nitric oxide, i.e., generated from iNOS, may have a pathogenic role in MS [105], it is possible that the transportation of nitric oxide by albumin could be beneficial or deleterious depending on whether it was being removed or delivered, respectively. Albumin also binds metals and heme. Included among the metals that bind albumin are copper [106] and iron [107]. These metals, and heme, can catalyze the formation of hydroxyl radical, but less so when bound to albumin, and the hydroxyl radical catalyzed from a metal bound to albumin is thought to largely interact with albumin itself rather than damaging other biologically relevant molecules [14, 15] (Fig. 1). Iron and heme can also catalyze the nitration of proteins [108-110], but when heme is bound to human serum albumin [103, 111-114] it may facilitate the detoxification of ROS and RNS [115-118]. The Cys34 on albumin can also form disulfide interactions with glutathione, cysteine, or homocysteine, while Arg410 and Lys525 are main targets of glycation $[15,119]$ (discussed below).

Iron and hemoglobin (e.g., extravasated RBCs) have been detected around damaged vessels in EAE and MS tissue [28, 32, 33, 40, 98, 120-122] (Fig. 1). This is also where extravasation of albumin originates thereby resulting in a high concentration at this site in comparison to albumin diffusing away from leaky vessels to other CNS structures and becoming diluted in the process (Fig. 1). Since iron and heme can catalyze reactions leading to oxidation and nitration [108-110, 123-125], it indicates that albumin is positioned to be an early recipient of these reactive species during BBB leakage (Fig. 1). Interestingly, nitrated proteins have been detected around vessels in EAE and MS [40, 126-128], and it has been

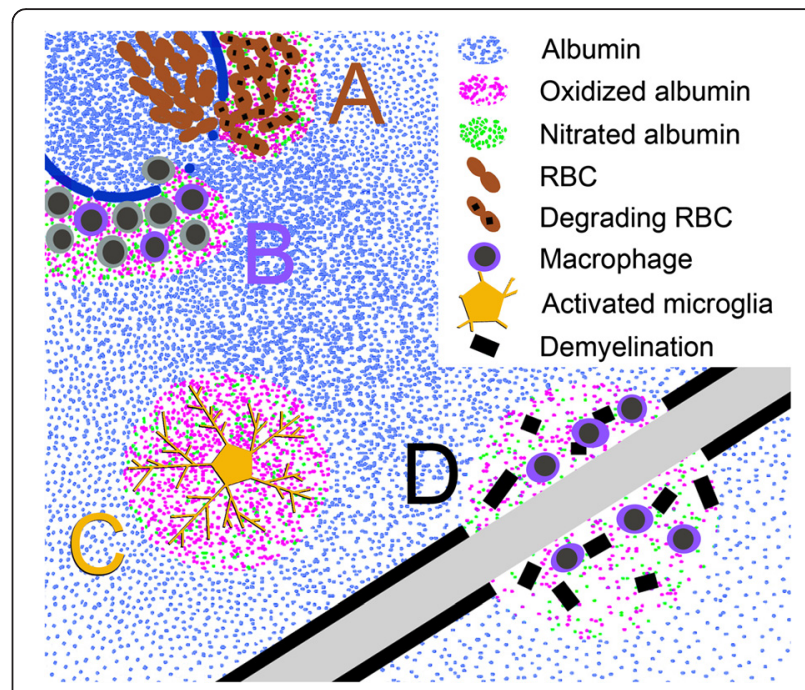

Fig. 1 Protective mechanisms by albumin in the CNS during active MS disease. a As a consequence of BBB damage, albumin (light blue dots) becomes extravasated and micro-hemorrhages (RBCs, rust color) can occur around vessels (royal blue) in MS CNS tissue. The RBCs breakdown (rust color with black spots) and heme/iron is released which can catalyze oxidation and nitration reactions. Albumin can bind heme and iron, which limits their ability to promote tissue damage. In addition, albumin is often the recipient of toxic species that are generated (pink dots - oxidized albumin; green dots - nitrated albumin), thereby protecting other CNS biomolecules. Albumin bound to heme may also detoxify ROS and RNS. b Inflammatory cells cross the BBB, and can be a source of ROS and RNS, particularly macrophages (e.g., M1 macrophages) (purple cells). The colocalization of albumin with macrophages positions albumin to be a target of ROS and RNS. c Besides macrophages, microglia that become activated during MS (yellow cell) can be a source of ROS and RNS. Extravasated albumin becomes a target for these toxic species and thereby limiting tissue damage to other important molecules in the CNS. $\mathbf{d}$ Myelin is a site of iron concentration, and during demyelination (black line fragments) iron is released. This iron can catalyze oxidation and nitration reactions together with inflammatory cells, e.g., macrophages. Albumin can be a recipient of reactive molecules and becomes modified. Note, the concentration of albumin would become diluted (top left to lower right) in relation to the distance from the site of the damaged (leaky) BBB, at least until an equilibrium is reached

put forth that extravasated albumin from leaky vessels is a main target for nitration during disease [40]. In addition, extravasated albumin is positioned to directly bind iron and heme originating from extravasated RBCs or liberated as a consequence of ongoing tissue damage, e.g., demyelination since iron can be abundant within myelin [129] (Fig. 1). This interaction with albumin would serve to limit the ability of iron and heme to form toxic radicals $[14,15]$, and act to possibly detoxify ROS and RNS [115-117]. The intravenous administration of albumin to rats with subarachnoid hemorrhage, modeled via endovascular perforation, resulted in improved behavioral outcomes and limited BBB leakage, and one mechanism for this effect could be the binding of heme and/or iron to albumin thereby limiting ROS and RNS damage [130]. 
Inflammatory cells, i.e., macrophages and reactive microglia, can also produce RNS and ROS during EAE and MS [88, 131-135]. Given that macrophages are a main participant in active lesions $[53-55,136]$, extravasated albumin could be a partial buffer limiting the spread of damage induced by these RNS and ROS to the surrounding tissue (Fig. 1). Analogously, myeloperoxidase has an elevated expression in macrophages and microglia in MS and it is thought to promote tissue damage [133, 137-139]. Since myeloperoxidase causes oxidation, nitration and nitrosylation to human serum albumin [140], it raises the possibility that albumin absorbs some of the toxic products of myeloperoxidase and thereby protecting more important biomolecules (Fig. 1).

In CSF from MS subjects, albumin becomes modified [141] and albumin fragments become carbonylated (which is thought to result from oxidative stress) [142]. Furthermore, ischemia modified albumin (IMA), which is thought to result from ROS-induced changes to the $\mathrm{N}$-terminus of albumin [143], and the IMA/albumin ratio are elevated in sera of patients with stable RRMS compared to control subjects [144].

Elevated levels of homocysteine have been associated with vascular injury and atrophy (or neurodegeneration) of some CNS structures [145, 146], and homocysteine and cysteine plasma levels are elevated in MS [147-149]. Albumin can regulate thiol/disulfide exchange reactions in plasma, and albumin is the main protein that binds homocysteine in plasma [147, 150, 151]. It has been put forth that homocysteine might promote toxicity to the CNS [146]; if so, then albumin could influence this process. For instance, the concentration of homocysteine is much greater in plasma than CSF [146]; thus, albumin might act as a carrier delivering homocysteine to the CNS at times of BBB leakage in MS and potentially worsening pathology. On the other hand, the binding homocysteine to albumin, and the rapid clearance of albumin from the CNS, e.g., in active lesions (discussed above), could limit the ability of homocysteine to promote toxicity.

\section{The putative synthesis of albumin by microglia}

Besides accessing the CNS following BBB leakage, albumin may be produced within the CNS. An in vitro and tissue study found that human microglia produce albumin and the expression increases upon microglial activation [152]. Albumin induction in the CNS was also observed following ischemia [153, 154]. Albumin produced by microglia was postulated to have a protective role in Alzheimer's disease by blocking the polymerization of amyloid beta and facilitating its clearance [152], and albumin produced in the CNS could have additional protective properties equivalent to those discussed above. However, in follow up studies, albumin that has become glycated was shown to be produced by rat and/or human microglial cells that were treated with amyloid beta or ethanol, and glycated albumin was suggested to promote neurodegeneration $[155,156]$. It is not known if glycated albumin is produced by microglial cells in MS. An elevation of glycated products has been observed in MS tissue [157, 158], but it is not clear if albumin was among the products, or if glycated products came from extravasation through a leaky BBB or were produced endogenously, e.g., in microglia. When albumin becomes glycated it diminishes its anti-oxidant properties [159-161], and in vitro studies found that exposure of rat retinal microglial cells to glycated albumin resulted in microglial production of proinflammatory cytokines, TNF $\alpha$ and IL-1 $\beta$ [162]. The expression of these cytokines is increased in MS [163] and may contribute to MS pathology including enhancing leakage of the BBB [136, 164]. Thus, glycated albumin might be in a position to worsen disease activity in MS, although it is unclear what the outcome would be if other molecules became glycated in place of albumin.

In contrast to glycated albumin, production of nonglycated albumin in the CNS is likely protective. However, it is still unclear whether albumin is produced by CNS cells in MS. In one study, albumin was detected within astrocytes, oligodendrocytes, axons, and macrophages in inactive plaques [7], which would support in situ synthesis, but additional studies are warranted, especially on active plaques, in order to fully establish which cells, if any, produce albumin in MS. Furthermore, even if albumin is synthesized in the CNS, it is unclear whether the amount produced will be sufficient to substantially influence albumin levels in the CSF or albumin levels in the CNS resulting from a breach in the $\mathrm{BBB}$.

\section{Albumin as a therapy in models of CNS diseases}

Albumin administered in high doses has been examined for therapeutic value in models of some CNS diseases. In models of ischemia (e.g., global, transient focal, or permanent focal) or traumatic brain injury, administration of albumin resulted in protection, e.g., reduced infarction volume $[165,166]$. Most of the benefits are thought to be related to hemodynamics effects, such as expanding the volume of the blood, but other mechanisms (similar to those discussed above) could also have protective roles [165]. In addition, the binding of albumin to megalin, a receptor on astrocytes [167], stimulates cultured astrocytes to produce oleic acid, which might support neuronal differentiation during development [168, 169]. Albumin also binds oleic acid [170], and treatment with albumin or albumin-oleic acid promoted recovery [171, 172] and decreased microglial activation [172] following spinal cord injury in the rat. 
Although it is possible that administration of exogenous albumin or albumin-oleic acid may confer some benefits for MS similar to the preclinical results described above for other conditions, high dose albumin therapy has been tested in clinical trials for ischemic stroke but was found to have no benefit, and it even increased mortality in subjects that were $>83$ years old [173]. The increased mortality in elderly individuals was suggested to be due to increased myocardial stress [174]; of note, there is evidence to suggest that MS patients have a greater risk for myocardial infarction [175]. Thus, great caution should be taken before pursuing a similar strategy in MS even if pre-clinical studies provide encouraging results.

\section{Possible pathogenic roles of albumin during MS}

Some studies obtained results suggesting that albumin has the potential to worsen disease activity in the CNS. For instance, injection of albumin into the neostriatum in one hemisphere resulted in a greater lesion volume compared to injection of saline into the other hemisphere in the rat [176] while infusion of serum or serum fraction(s) in CA1 sector or striatum led to neuronal loss or inflammatory lesions in these respective locations [177]. However, the outcomes observed in these studies could have been due to factors other than the injected albumin or serum components. For instance, the osmotic effects of albumin or serum proteins, and/or the large volume of injected material may account for the lesions since a slow injection of plasma proteins into the hippocampus did not cause neurodegeneration [178]. In another study, an intracerebroventricular injection of albumin didn't result in neurodegeneration in rats, however, when it was combined with hippocampal administration of kainic acid, which is used to induce seizures, neurodegeneration of CA3 neurons was enhanced compared to kainic acid plus vehicle [179].

Seizure activity is associated with an opening of the $\mathrm{BBB}$, and extravasation of albumin into the brain is thought to increase the excitability of neurons and induce proinflammatory events. For example, a model of status epilepticus in rats resulted in extravasation of albumin in the hippocampus, which was diffusely distributed at $2 \mathrm{~h}$ post status epilepticus and became concentrated in CA3 neurons at $24 \mathrm{~h}$ [179]. An intracerebroventricular injection of albumin resulted in high frequency, high amplitude spiking activity in the rat hippocampus lasting $1 \mathrm{~h}$ after injection, and induced IL$1 \beta$ expression by hippocampal astrocytes at $2 \mathrm{~h}$, which was further increased by $24 \mathrm{~h}$ [179]. Besides induction in astrocytes, albumin can induce microglia to express IL-1 $\beta$ [180]. In studies involving CSF from MS patients with active disease, together with in vitro mouse brain slice preparations and other related analyses, IL-1 $\beta$ was found to be associated with inducing excitatory postsynaptic currents and glutamate excitotoxic neuronal damage [181]. Albumin can also induce other inflammatory responses by astrocytes and microglia. For example, albumin can induce astrocytic expression of CX3CL1 [180], which is a chemokine involved in CNS recruitment of CD4+ T cells in RRMS [182], and albumin can induce microglial activation, i.e., increase intracellular levels of calcium and proliferation [183]. Albumin can also induce astroglial and microglial expression of nitric oxide metabolites [180].

Both the prevalence and incidence of seizure disorders is greater in MS patients than in the general population [184], but even without seizures, it is possible that leakage of albumin through a damaged BBB in MS could lead to some similar pathogenic events that occur in epilepsy. Epilepsy results in BBB leakage and extravasation of albumin into CNS structures, and the presence of albumin is thought to exacerbate disease by inducing inflammatory events (discussed above) and by altering potassium homeostasis [76]. In the CNS, extravasated or exogenously administered albumin results in its presence in the parenchyma and uptake by microglia, astrocytes and neurons [73-76] leading to astrocyte gliosis and neuronal loss [185]. Mechanistically, albumin is thought to enter astrocytes after interacting with TGF- $\beta$ receptors and this uptake affects calcium concentrations in the cytoplasm [186] and results in the downregulation of Kir4.1 in astrocytes [73, 76, 179]. Extracellular potassium homeostasis becomes disrupted [73, 187] and neurons may become hyper-excitable to NMDA receptor activation [73, 76]. Also, albumin in neurons can increase the synthesis of glutamate [188] furthering this cycle. Since glutamate has been implicated in neurodegeneration in MS [189], it suggests that albumin could amplify pathology via this mechanism involving disruption of potassium homeostasis leading to greater sensitivity to glutamate.

Kir4.1 is localized to oligodendrocytes, perivascular astrocytes, astrocyte endfeet, and astrocyte processes associated with synapses $[190,191]$. Interestingly, autoantibodies to Kir4.1 are at higher levels in MS than in controls, and are increased during a disease relapse compared to remission [192, 193], but their presence and/or role in MS have been questioned [194-196]. The expression of Kir4.1 is altered in MS lesions; in acute or chronic active demyelinating lesions Kir4.1 levels decreased while periplaque reactive astrocytes had increased levels [191]. Similar to its actions in epilepsy, it is possible that extravasated albumin can influence Kir4.1 expression in MS, and further dysregulation of Kir4.1 expression could facilitate the neurodegenerative process. 


\section{Conclusions}

In MS, CNS cells can become bathed by albumin in the context of ongoing inflammation following BBB disruption. Although many functions have been attributed to albumin, its role in MS has received little attention.

Damage to the BBB in MS is relatively common, and given the high concentration of albumin in plasma, it readily passes from the circulation into the CNS during $\mathrm{BBB}$ leakage. Although the albumin quotient is used as an indication of blood-CSF dysfunction, many factors can influence the CSF concentration of albumin indicating that this measurement is an imprecise indicator of BBB leakage or blood-CSF dysfunction. Once albumin becomes extravasated into the CNS, it can exert beneficial and/or harmful effects. Beneficial actions include albumin being a target for ROS and RNS, and in so doing limiting damage to other molecules. Albumin can also reduce the production of ROS and RNS by binding iron and heme. Despite these protective properties, albumin may promote pathology by acting to induce the production of proinflammatory cytokines, or disrupting potassium homeostasis making neurons potentially more vulnerable to glutamate excitotoxicity. Given the abundance of albumin together with frequent disruptions to the $\mathrm{BBB}$, further studies are warranted to advance the understanding of the impact that albumin has on cellular functions and pathogenic processes in the context of MS. Some other pertinent areas of research include investigations on the roles of albumin variants, modified albumin (e.g., glycated albumin), and albumin levels on the disease course. Additionally, detailing the role of albumin in relation to the delivery or action of disease modifying therapies, and other drugs that are used to treat MS patients, is of interest.

In summary, given that albumin represents such a large percentage of the proteins that become extravasated during $\mathrm{BBB}$ leakage, albumin likely performs a multitude of roles that are largely dependent on the microenvironment albumin becomes exposed to during disease.

\section{Abbreviations \\ BBB: blood-brain barrier; CNS: central nervous system; EAE: experimental autoimmune encephalomyelitis; Gd: gadolinium; IMA: ischemia modified albumin; MS: multiple sclerosis; PPMS: primary progressive multiple sclerosis; RBCs: red blood cells; RNS: reactive nitrogen species; ROS: reactive oxygen species; RRMS: relapsing remitting multiple sclerosis; SPMS: secondary progressive multiple sclerosis.}

\section{Competing interest}

SML has performed explorations into the possible development of an assay involving albumin with a goal of potential commercialization. Unrelated to this effort, SML has received past and current research funding from ApoPharma, Inc.

\section{Acknowledgements}

The One University Open Access Author Fund at The University of Kansas and intramural funds were used to pay for publication costs.
Received: 8 January 2016 Accepted: 24 March 2016

Published online: 12 April 2016

\section{References}

1. Karussis D. The diagnosis of multiple sclerosis and the various related demyelinating syndromes: a critical review. J Autoimmun. 2014;48-49:134-42.

2. Milo R, Miller A. Revised diagnostic criteria of multiple sclerosis. Autoimmun Rev. 2014;13:518-24.

3. Katz D, Taubenberger JK, Cannella B, McFarlin DE, Raine CS, McFarland HF. Correlation between magnetic resonance imaging findings and lesion development in chronic, active multiple sclerosis. Ann Neurol. 1993;34:661-9.

4. Brück W, Bitsch A, Kolenda H, Brück Y, Stiefel M, Lassmann H. Inflammatory central nervous system demyelination: correlation of magnetic resonance imaging findings with lesion pathology. Ann Neurol. 1997:42:783-93.

5. Larochelle C, Alvarez JI, Prat A. How do immune cells overcome the bloodbrain barrier in multiple sclerosis? FEBS Lett. 2011;585:3770-80.

6. Vos CM, Geurts JJ, Montagne L, van Haastert ES, Bö L, van der Valk P, Barkhof F, de Vries HE. Blood-brain barrier alterations in both focal and diffuse abnormalities on postmortem MRI in multiple sclerosis. Neurobiol Dis. 2005;20:953-60.

7. Kwon EE, Prineas JW. Blood-brain barrier abnormalities in longstanding multiple sclerosis lesions. An immunohistochemical study. J Neuropathol Exp Neurol. 1994;53:625-36.

8. Claudio, Raine CS, Brosnan CF. Evidence of persistent blood-brain barrier abnormalities in chronic-progressive multiple sclerosis. Acta Neuropathol. 1995;90:228-38

9. Filippi M, Rocca MA, Martino G, Horsfield MA, Comi G. Magnetization transfer changes in the normal appearing white matter precede the appearance of enhancing lesions in patients with multiple sclerosis. Ann Neurol. 1998;43:809-14.

10. Goodkin DE, Rooney WD, Sloan R, Bacchetti P, Gee L, Vermathen M, Waubant E, Abundo M, Majumdar S, Nelson S, Weiner MW. A serial study of new MS lesions and the white matter from which they arise. Neurology. 1998;51:1689-97.

11. Werring DJ, Brassat D, Droogan AG, Clark CA, Symms MR, Barker GJ, MacManus DG, Thompson AJ, Miller DH. The pathogenesis of lesions and normal-appearing white matter changes in multiple sclerosis: a serial diffusion MRI study. Brain. 2000;123:1667-76.

12. Plumb J, McQuaid S, Mirakhur M, Kirk J. Abnormal endothelial tight junctions in active lesions and normal-appearing white matter in multiple sclerosis. Brain Pathol. 2002;12:154-69.

13. Guttmann CR, Rousset M, Roch JA, Hannoun S, Durand-Dubief F, Belaroussi B, Cavallari M, Rabilloud M, Sappey-Marinier D, Vukusic S, Cotton F. Multiple sclerosis lesion formation and early evolution revisited: A weekly highresolution magnetic resonance imaging study. Mult Scler. In press.

14. Roche M, Rondeau P, Singh NR, Tarnus E, Bourdon E. The antioxidant properties of serum albumin. FEBS Lett. 2008;582:1783-7.

15. Fanali G, di Masi A, Trezza V, Marino M, Fasano M, Ascenzi P. Human serum albumin: from bench to bedside. Mol Aspects Med. 2012;33:209-90.

16. Lublin FD. New multiple sclerosis phenotypic classification. Eur Neurol. 2014, 72 Suppl 1:1-5.

17. Polman CH, Reingold SC, Banwell B, Clanet M, Cohen JA, Filippi M, Fujihara K, Havrdova E, Hutchinson M, Kappos L, Lublin FD, Montalban X, O'Connor P, Sandberg-Wollheim M, Thompson AJ, Waubant E, Weinshenker B, Wolinsky JS. Diagnostic criteria for multiple sclerosis: 2010 revisions to the McDonald criteria. Ann Neurol. 2011;69:292-302

18. Filippi M, Capra R, Campi A, Colombo B, Prandini F, Marcianò N, Gasparotti R, Comi G. Triple dose of gadolinium-DTPA and delayed MRI in patients with benign multiple sclerosis. J Neurol Neurosurg Psychiatry. 1996;60:526-30.

19. Silver NC, Good CD, Barker GJ, MacManus DG, Thompson AJ, Moseley IF, McDonald WI, Miller DH. Sensitivity of contrast enhanced MRI in multiple sclerosis. Effects of gadolinium dose, magnetization transfer contrast and delayed imaging. Brain. 1997;120:1149-61.

20. Paolillo A, Piattella MC, Pantano P, Di Legge S, Caramia F, Russo P, Lenzi GL, Pozzilli $C$. The relationship between inflammation and atrophy in clinically isolated syndromes suggestive of multiple sclerosis: a monthly MRI study after triple-dose gadolinium-DTPA. J Neurol. 2004;251:432-9.

21. Ingle GT, Sastre-Garriga J, Miller DH, Thompson AJ. Is inflammation important in early PPMS? a longitudinal MRI study. J Neurol Neurosurg Psychiatry. 2005;76:1255-8. 
22. Khaleeli Z, Ciccarelli O, Mizskiel K, Altmann D, Miller DH, Thompson AJ. Lesion enhancement diminishes with time in primary progressive multiple sclerosis. Mult Scler. 2010;16:317-24.

23. Ghezzi A, Moiola L, Pozzilli C, Brescia-Morra V, Gallo P, Grimaldi LM, Filippi M, G GC. Natalizumab in the pediatric MS population: results of the Italian registry. BMC Neurol. 2015;15:174

24. McDonald WI, Miller DH, Barnes D. The pathological evolution of multiple sclerosis. Neuropathol Appl Neurobiol. 1992;18:319-34.

25. He J, Grossman Rl, Ge Y, Mannon $\sqcup$. Enhancing patterns in multiple sclerosis: evolution and persistence. AJNR Am J Neuroradiol. 2001;22:664-9.

26. Filippi M, Yousry T, Campi A, Kandziora C, Colombo B, Voltz R, Martinelli V, Spuler S, Bressi S, Scotti G, Comi G. Comparison of triple dose versus standard dose gadolinium-DTPA for detection of MRI enhancing lesions in patients with MS. Neurology. 1996;46:379-84.

27. Filippi M, Rovaris M, Capra R, Gasperini C, Yousry TA, Sormani MP, Prandini F, Horsfield MA, Martinelli V, Bastianello S, Kühne I, Pozzilli C, Comi G. A multi-centre longitudinal study comparing the sensitivity of monthly MRI after standard and triple dose gadolinium-DTPA for monitoring disease activity in multiple sclerosis. Implications for phase II clinical trials. Brain. 1998;121:2011-20

28. Forge JK, Pedchenko TV, LeVine SM. Iron deposits in the central nervous system of SJL mice with experimental allergic encephalomyelitis. Life Sci. 1998;63:2271-84

29. Williams R, Rohr AM, Wang WT, Choi IY, Lee P, Berman NE, Lynch SG, LeVine SM. Iron deposition is independent of cellular inflammation in a cerebral model of multiple sclerosis. BMC Neurosci. 2011;12:59.

30. Farias AS, Martins-de-Souza D, Guimarães L, Pradella F, Moraes AS, Facchini G, Novello JC, Santos LM. Proteome analysis of spinal cord during the clinical course of monophasic experimental autoimmune encephalomyelitis. Proteomics. 2012;12:2656-62.

31. Rosenling T, Stoop MP, Attali A, van Aken H, Suidgeest E, Christin C, Stingl C, Suits F, Horvatovich P, Hintzen RQ, Tuinstra T, Bischoff R, Luider TM. Profiling and identification of cerebrospinal fluid proteins in a rat EAE model of multiple sclerosis. J Proteome Res. 2012;11:2048-60.

32. Adams CW. Perivascular iron deposition and other vascular damage in multiple sclerosis. J Neurol Neurosurg Psychiatry. 1988:51:260-5.

33. Adams CW. A color atlas of multiple sclerosis and other myelin disorders. Dobbs Ferry, NY: Sheridan House Inc:; 1989.

34. Gay FW, Drye TJ, Dick GW, Esiri MM. The application of multifactoria cluster analysis in the staging of plaques in early multiple sclerosis. Identification and characterization of the primary demyelinating lesion. Brain. 1997;120:1461-83.

35. Han MH, Hwang SI, Roy DB, Lundgren DH, Price JV, Ousman SS, Fernald GH, Gerlitz B, Robinson WH, Baranzini SE, Grinnell BW, Raine CS, Sobel RA, Han DK, Steinman L. Proteomic analysis of active multiple sclerosis lesions reveals therapeutic targets. Nature. 2008;451:1076-81.

36. Duzhak T, Emerson MR, Chakrabarty A, Alterman MA, LeVine SM. Analysis of protein induction in the CNS of SJL mice with experimental allergic encephalomyelitis by proteomic screening and immunohistochemistry. Cell Mol Biol (Noisy-le-Grand). 2003;49:723-32.

37. Traugott U, Raine CS, McFarlin DE. Acute experimental allergic encephalomyelitis in the mouse: immunopathology of the developing lesion. Cell Immunol. 1985:91:240-54.

38. Juhler M, Laursen H, Barry DI. The distribution of immunoglobulins and albumin in the central nervous system in acute experimental allergic encephalomyelitis. Acta Neurol Scand. 1986;73:119-24.

39. Emerson MR, Orentas DM, Lynch SG, LeVine SM. Activation of histamine H2 receptors ameliorates experimental allergic encephalomyelitis. Neuroreport. 2002;13:1407-10

40. Sands SA, Williams R, Marshall 3rd S, LeVine SM. Perivascular iron deposits are associated with protein nitration in cerebral experimental autoimmune encephalomyelitis. Neurosci Lett. 2014;582:133-8.

41. Kerlero de Rosbo N, Bernard CC, Simmons RD, Carnegie PR. Concomitant detection of changes in myelin basic protein and permeability of bloodspinal cord barrier in acute experimental autoimmune encephalomyelitis by electroimmunoblotting. J Neuroimmunol. 1985:9:349-61.

42. Kristensson K, Wiśniewski HM. Chronic relapsing experimental allergic encephalomyelitis. Studies in vascular permeability changes. Acta Neuropathol. 1977;39:189-94.

43. Suckling AJ, Reiber $H$, Kirby JA, Rumsby MG. Chronic relapsing experimental allergic encephalomyelitis. Immunological and blood-cerebrospinal fluid barrier-dependent changes in the cerebrospinal fluid. J Neuroimmunol. 1983;4:35-45.

44. Kitz K, Lassmann H, Karcher D, Lowenthal A. Blood-brain barrier in chronic relapsing experimental allergic encephalomyelitis: a correlative study between cerebrospinal fluid protein concentrations and tracer leakage in the central nervous system. Acta Neuropathol. 1984;63:41-50.

45. Goldmuntz EA, Brosnan CF, Norton WT. Prazosin treatment suppresses increased vascular permeability in both acute and passively transferred experimental autoimmune encephalomyelitis in the Lewis rat. J Immunol. 1986;137:3444-50

46. Sobel RA, Mitchell ME. Fibronectin in multiple sclerosis lesions. Am J Pathol. 1989;135:161-8.

47. Ly L, Barnett MH, Zheng YZ, Gulati T, Prineas JW, Crossett B. Comprehensive tissue processing strategy for quantitative proteomics of formalin-fixed multiple sclerosis lesions. J Proteome Res. 2011:10:4855-68.

48. FDA. http://www.fda.gov/downloads/Drugs/DevelopmentApprovalProcess/ DevelopmentResources/UCM354675.pdf. Access 6 Apr 2016.

49. Kremer S, Lamy J, Magnus A, Oesterle H, Jeantroux J, Trunet S, Armspach JP, Dietemann $J$, de Sèze J. Evaluation of an albumin-binding gadolinium contrast agent in multiple sclerosis. Neurology. 2013;81:206-10.

50. Adams CW, Poston RN, Buk SJ, Sidhu YS, Vipond H. Inflammatory vasculitis in multiple sclerosis. J Neurol Sci. 1985;69:269-83.

51. Kirk J, Plumb J, Mirakhur M, McQuaid S. Tight junctional abnormality in multiple sclerosis white matter affects all calibres of vessel and is associated with blood-brain barrier leakage and active demyelination. J Pathol. 2003;201:319-27.

52. Faustmann PM, Teutrine S, Krause D, Dermietzel R. Subarachnoidal macrophages share a common epitope with resident non-cerebral macrophages and show receptor-mediated endocytosis of albumin-gold and lgG-gold complexes. J Neuroimmunol. 1991;35:79-88.

53. Adams CW, Poston RN. Macrophage histology in paraffin-embedded multiple sclerosis plaques is demonstrated by the monoclonal panmacrophage marker HAM-56: correlation with chronicity of the lesion. Acta Neuropathol. 1990:80:208-11.

54. Lassmann H, Suchanek G, Ozawa K. Histopathology and the bloodcerebrospinal fluid barrier in multiple sclerosis. Ann Neurol. 1994;36(Suppl):S42-6.

55. Brück W, Sommermeier N, Bergmann M, Zettl U, Goebel HH, Kretzschmar HA, Lassmann H. Macrophages in multiple sclerosis. Immunobiology. 1996:195:588-600.

56. D’Aguanno S, Barassi A, Lupisella S, d'eril GM, Del Boccio P, Pieragostino D, Pallotti F, Carelli V, Valentino ML, Liguori R, Avoni P, Bernardini S, Gambi D, Urbani A, Federici G. Differential cerebro spinal fluid proteome investigation of Leber hereditary optic neuropathy (LHON) and multiple sclerosis. J Neuroimmunol. 2008:193:156-60.

57. Kabat EA, Freedman DA, Murray JP, Knaub V. A study of the crystalline albumin, gamma globulin and total protein in the cerebrospinal fluid of 100 cases of multiple sclerosis and in other diseases. Am J Med Sci. 1950;219: $55-64$.

58. Eickhoff K, Wikström J, Poser S, Bauer H. Protein profile of cerebrospinal fluid in multiple sclerosis with special reference to the function of the blood brain barrier. J Neurol. 1977;214:207-15.

59. Link $H$, Tibbling $G$. Principles of albumin and lgG analyses in neurological disorders. III. Evaluation of IgG synthesis within the central nervous system in multiple sclerosis. Scand J Clin Lab Invest. 1977:37:397-401.

60. Tourtellotte WW, Ma BI. Multiple sclerosis: the blood-brain-barrier and the measurement of de novo central nervous system lgG synthesis. Neurology. 1978;28:76-83.

61. Andersson M, Alvarez-Cermeño J, Bernardi G, Cogato I, Fredman P, Frederiksen J, Fredrikson S, Gallo P, Grimaldi LM, Grønning M. Cerebrospinal fluid in the diagnosis of multiple sclerosis: a consensus report. J Neurol Neurosurg Psychiatry. 1994;57:897-902.

62. Uher T, Horakova D, Tyblova M, Zeman D, Krasulova E, Mrazova K, Seidl Z, Vaneckova M, Krasensky J, Weinstock-Guttman B, Ramanathan M, Havrdova E, Zivadinov R. Increased albumin quotient (QAlb) in patients after first clinical event suggestive of multiple sclerosis is associated with development of brain atrophy and greater disability 48 months later. Mult Scler. Epub ahead of print.

63. Freedman MS, Thompson EJ, Deisenhammer F, Giovannoni G, Grimsley G, Keir G, Ohman S, Racke MK, Sharief M, Sindic CJ, Sellebjerg F, Tourtellotte WW. Recommended standard of cerebrospinal fluid analysis in the 
diagnosis of multiple sclerosis: a consensus statement. Arch Neurol. 2005;62:865-70.

64. Liebsch R, Kornhuber ME, Dietl D, Gräfin von Einsiedel H, Conrad B. Blood-CSF barrier integrity in multiple sclerosis. Acta Neurol Scand. 1996;94:404-10

65. Hegen $\mathrm{H}$, Auer M, Zeileis A, Deisenhammer F. Upper reference limits for cerebrospinal fluid total protein and albumin quotient based on a large cohort of control patients: implications for increased clinical specificity. Clin Chem Lab Med. 2015. doi: 10.1515/cclm-2015-0253.

66. Cserr HF, Cooper DN, Suri PK, Patlak CS. Efflux of radiolabeled polyethylene glycols and albumin from rat brain. Am J Physiol. 1981; 240:F319-28.

67. Ling C, Sandor M, Fabry Z. In situ processing and distribution of intracerebrally injected OVA in the CNS. J Neuroimmunol. 2003;141:90-8.

68. Liddelow SA, Dzięgielewska KM, Møllgård K, Whish SC, Noor NM, Wheaton BJ, Gehwolf R, Wagner A, Traweger A, Bauer H, Bauer HC, Saunders NR. Cellular specificity of the blood-CSF barrier for albumin transfer across the choroid plexus epithelium. PLoS One. 2014;9:e106592.

69. Johanson CE, Duncan 3rd JA, Klinge PM, Brinker T, Stopa EG, Silverberg GD. Multiplicity of cerebrospinal fluid functions: New challenges in health and disease. Cerebrospinal Fluid Res. 2008:5:10.

70. Rudick RA, Zirretta DK, Herndon RM. Clearance of albumin from mouse subarachnoid space: a measure of CSF bulk flow. J Neurosci Methods. 1982;6:253-9.

71. Magnano C, Schirda C, Weinstock-Guttman B, Wack DS, Lindzen E, Hojnacki D, Bergsland N, Kennedy C, Belov P, Dwyer MG, Poloni GU, Beggs CB, Zivadinov R. Cine cerebrospinal fluid imaging in multiple sclerosis. J Magn Reson Imaging. 2012;36:825-34

72. Reiber H. Proteins in cerebrospinal fluid and blood: barriers, CSF flow rate and source-related dynamics. Restor Neurol Neurosci. 2003;21: 79-96.

73. Ivens S, Kaufer D, Flores LP, Bechmann I, Zumsteg D, Tomkins O, Seiffert E, Heinemann U, Friedman A. TGF-beta receptor-mediated albumin uptake into astrocytes is involved in neocortical epileptogenesis. Brain. 2007;130:535-47.

74. van Vliet EA, da Costa AS, Redeker S, van Schaik R, Aronica E, Gorter JA. Blood-brain barrier leakage may lead to progression of temporal lobe epilepsy. Brain. 2007;130:521-34.

75. Braganza O, Bedner P, Hüttmann K, von Staden E, Friedman A, Seifert G, Steinhäuser C. Albumin is taken up by hippocampal NG2 cells and astrocytes and decreases gap junction coupling. Epilepsia. 2012;53:1898-906.

76. van Vliet EA, Aronica E, Gorter JA. Blood-brain barrier dysfunction, seizures and epilepsy. Semin Cell Dev Biol. 2015;38:26-34.

77. Werb Z, Bainton DF, Jones PA. Degradation of connective tissue matrices by macrophages. III. Morphological and biochemical studies on extracellular, pericellular, and intracellular events in matrix proteolysis by macrophages in culture. J Exp Med. 1980;152:1537-53.

78. Kam CM, Hudig D, Powers JC. Granzymes (lymphocyte serine proteases): characterization with natural and synthetic substrates and inhibitors. Biochim Biophys Acta. 2000;1477:307-23.

79. Finehout EJ, Franck Z, Lee KH. Towards two-dimensional electrophoresis mapping of the cerebrospinal fluid proteome from a single individual. Electrophoresis. 2004;25:2564-75.

80. Vento G, Tirone C, Lulli P, Capoluongo E, Ameglio F, Lozzi S, Cota F, Mosca F, Romagnoli C, Messana I, Castagnola M, Inzitari R. Bronchoalveolar lavage fluid peptidomics suggests a possible matrix metalloproteinase-3 role in bronchopulmonary dysplasia. Intensive Care Med. 2009;35:2115-24.

81. Ljubisavljevic S, Stojanovic I, Basic J, Vojinovic S, Stojanov D, Djordjevic G, Pavlovic D. The Role of Matrix Metalloproteinase 3 and 9 in the Pathogenesis of Acute Neuroinflammation. Implications for Disease Modifying Therapy. J Mol Neurosci. 2015;56:840-7.

82. Kanesaka T, Mori M, Hattori T, Oki T, Kuwabara S. Serum matrix metalloproteinase-3 levels correlate with disease activity in relapsing-remitting multiple sclerosis. J Neurol Neurosurg Psychiatry. 2006;77:185-8.

83. Rosenberg GA, Cunningham LA, Wallace J, Alexander S, Estrada EY, Grossetete M, Razhagi A, Miller K, Gearing A. Immunohistochemistry of matrix metalloproteinases in reperfusion injury to rat brain: activation of MMP-9 linked to stromelysin-1 and microglia in cell cultures. Brain Res. 2001;893:104-12.
84. Van Hove I, Lemmens K, Van de Velde S, Verslegers M, Moons L. Matrix metalloproteinase-3 in the central nervous system: a look on the bright side. J Neurochem. 2012;123:203-16.

85. Mirshafiey A, Asghari B, Ghalamfarsa G, Jadidi-Niaragh F, Azizi G. The significance of matrix metalloproteinases in the immunopathogenesis and treatment of multiple sclerosis. Sultan Qaboos Univ Med J. 2014;14:e13-25

86. Maeda A, Sobel RA. Matrix metalloproteinases in the normal human central nervous system, microglial nodules, and multiple sclerosis lesions. J Neuropathol Exp Neurol. 1996;55:300-9.

87. Fisher $\mathrm{M}$, Levine $\mathrm{PH}$, Weiner $\mathrm{BH}$, Vaudreuil $\mathrm{CH}$, Natale A, Johnson $\mathrm{MH}$, Hoogasian JJ. Monocyte and polymorphonuclear leukocyte toxic oxygen metabolite production in multiple sclerosis. Inflammation. 1988;12:123-31.

88. Ruuls SR, Bauer J, Sontrop K, Huitinga I, 't Hart BA. Dijkstra CD Reactive oxygen species are involved in the pathogenesis of experimental allergic encephalomyelitis in Lewis rats. J Neuroimmunol. 1995;56:207-17.

89. Oleszak EL, Zaczynska E, Bhattacharjee M, Butunoi C, Legido A, Katsetos CD. Inducible nitric oxide synthase and nitrotyrosine are found in monocytes/ macrophages and/or astrocytes in acute, but not in chronic, multiple sclerosis. Clin Diagn Lab Immunol. 1998:5:438-45.

90. Brundin L, Morcos E, Olsson T, Wiklund NP, Andersson M. Increased intrathecal nitric oxide formation in multiple sclerosis; cerebrospinal fluid nitrite as activity marker. Eur J Neurol. 1999;6:585-90.

91. Calabrese V, Scapagnini G, Ravagna A, Bella R, Foresti R, Bates TE, Giuffrida Stella AM, Pennisi G. Nitric oxide synthase is present in the cerebrospinal fluid of patients with active multiple sclerosis and is associated with increases in cerebrospinal fluid protein nitrotyrosine and S-nitrosothiols and with changes in glutathione levels. J Neurosci Res. 2002;70:580-7.

92. LeVine SM, Chakrabarty A. The role of iron in the pathogenesis of experimental allergic encephalomyelitis and multiple sclerosis. Ann N Y Acad Sci. 2004;1012:252-66.

93. Bizzozero OA, Dejesus G, Bixler HA, Pastuszyn A. Evidence of nitrosative damage in the brain white matter of patients with multiple sclerosis. Neurochem Res. 2005:30:139-49.

94. Koch M, Mostert J, Arutjunyan A, Stepanov M, Teelken A, Heersema D, De Keyser J. Peripheral blood leukocyte NO production and oxidative stress in multiple sclerosis. Mult Scler. 2008;14:159-65.

95. Rejdak K, Petzold A, Stelmasiak Z, Giovannoni G. Cerebrospinal fluid brain specific proteins in relation to nitric oxide metabolites during relapse of multiple sclerosis. Mult Scler. 2008;14:59-66.

96. Ortiz GG, Macías-Islas MA, Pacheco-Moisés FP, Cruz-Ramos JA, Sustersik S, Barba EA, Aguayo A. Oxidative stress is increased in serum from Mexican patients with relapsing-remitting multiple sclerosis. Dis Markers. 2009;26:35-9.

97. Haider L, Fischer MT, Frischer JM, Bauer J, Höftberger R, Botond G, Esterbauer H, Binder $\mathrm{CJ}$, Witztum JL, Lassmann H. Oxidative damage in multiple sclerosis lesions. Brain. 2011;134:1914-24.

98. Hametner S, Wimmer I, Haider L, Pfeifenbring S, Brück W, Lassmann H. Iron and neurodegeneration in the multiple sclerosis brain. Ann Neurol. 2013;74:848-61.

99. Wang $\mathrm{P}$, Xie K, Wang C, Bi J. Oxidative stress induced by lipid peroxidation is related with inflammation of demyelination and neurodegeneration in multiple sclerosis. Eur Neurol. 2014;72:249-54.

100. Colombo G, Clerici M, Giustarini D, Rossi R, Milzani A, Dalle-Donne I. Redox albuminomics: oxidized albumin in human diseases. Antioxid Redox Signal. 2012;17:1515-27.

101. Jiao K, Mandapati S, Skipper PL, Tannenbaum SR, Wishnok JS. Site-selective nitration of tyrosine in human serum albumin by peroxynitrite. Anal Biochem. 2001;293:43-52.

102. Carballal S, Radi R, Kirk MC, Barnes S, Freeman BA, Alvarez B. Sulfenic acid formation in human serum albumin by hydrogen peroxide and peroxynitrite. Biochemistry. 2003;42:9906-14.

103. Stamler JS, Jaraki O, Osborne J, Simon DI, Keaney J, Vita J, Singel D, Valeri $\mathrm{CR}$, Loscalzo J. Nitric oxide circulates in mammalian plasma primarily as an S-nitroso adduct of serum albumin. Proc Natl Acad Sci U S A. 1992:89:7674-7.

104. Keaney Jr JF, Simon DI, Stamler JS, Jaraki O, Scharfstein J, Vita JA, Loscalzo J. $\mathrm{NO}$ forms an adduct with serum albumin that has endothelium-derived relaxing factor-like properties. J Clin Invest. 1993;91:1582-9. 
105. Ghasemi M, Fatemi A. Pathologic role of glial nitric oxide in adult and pediatric neuroinflammatory diseases. Neurosci Biobehav Rev. 2014:45:168-82.

106. Laussac JP, Sarkar B. Characterization of the copper(II)- and nickel(II)transport site of human serum albumin. Studies of copper(II) and nickel(II) binding to peptide 1-24 of human serum albumin by $13 \mathrm{C}$ and $1 \mathrm{H}$ NMR spectroscopy. Biochemistry. 1984;23:2832-8.

107. Loban A, Kime R, Powers H. Iron-binding antioxidant potential of plasma albumin. Clin Sci (Lond). 1997;93:445-51.

108. Pfeiffer S, Lass A, Schmidt K, Mayer B. Protein tyrosine nitration in cytokineactivated murine macrophages. Involvement of a peroxidase/nitrite pathway rather than peroxynitrite. J Biol Chem. 2001;276:34051-8.

109. Thomas DD, Espey MG, Vitek MP, Miranda KM, Wink DA. Protein nitration is mediated by heme and free metals through Fenton-type chemistry: an alternative to the NO/O2- reaction. Proc Natl Acad Sci U S A. 2002;99:12691-6.

110. Bian K, Gao Z, Weisbrodt N, Murad F. The nature of heme/iron-induced protein tyrosine nitration. Proc Natl Acad Sci U S A. 2003;100:5712-7.

111. Wardell M, Wang Z, Ho JX, Robert J, Ruker F, Ruble J, Carter DC. The atomic structure of human methemalbumin at 1.9 A. Biochem Biophys Res Commun. 2002;291:813-9.

112. Zunszain PA, Ghuman J, Komatsu T, Tsuchida E, Curry S. Crystal structural analysis of human serum albumin complexed with hemin and fatty acid. BMC Struct Biol. 2003;3:6

113. Fasano $M$, Fanali $G$, Leboffe $L$, Ascenzi P. Heme binding to albuminoid proteins is the result of recent evolution. IUBMB Life. 2007;59:436-40.

114. Ascenzi P, Fasano M. Serum heme-albumin: an allosteric protein. IUBMB Life. 2009;61:1118-22.

115. Monzani E, Bonafè B, Fallarini A, Redaelli C, Casella L, Minchiotti L, Galliano M. Enzymatic properties of human hemalbumin. Biochim Biophys Acta. 2001;1547:302-12.

116. Ascenzi P, Fasano M. Abacavir modulates peroxynitrite-mediated oxidation of ferrous nitrosylated human serum heme-albumin. Biochem Biophys Res Commun. 2007;353:469-74.

117. Ascenzi P, di Masi A, De Sanctis G, Coletta M, Fasano M. Ibuprofen modulates allosterically NO dissociation from ferrous nitrosylated human serum heme-albumin by binding to three sites. Biochem Biophys Res Commun. 2009;387:83-6.

118. Huang Y, Shuai Y, Li H, Gao Z. Tyrosine residues play an important role in heme detoxification by serum albumin. Biochim Biophys Acta. 1840;2014:970-6.

119. Taverna M, Marie AL, Mira JP, Guidet B. Specific antioxidant properties of human serum albumin. Ann Intensive Care. 2013;3:4.

120. Bagnato F, Hametner S, Yao B, van Gelderen P, Merkle H, Cantor FK, Lassmann H, Duyn JH. Tracking iron in multiple sclerosis: a combined imaging and histopathological study at 7 Tesla. Brain. 2011;134:3602-15.

121. Mehta V, Pei W, Yang G, Li S, Swamy E, Boster A, Schmalbrock P, Pitt D. Iron is a sensitive biomarker for inflammation in multiple sclerosis lesions. PLOS One. 2013;8:e57573.

122. Bamm W, Harauz G. Hemoglobin as a source of iron overload in multiple sclerosis: does multiple sclerosis share risk factors with vascular disorders? Cell Mol Life Sci. 2014;71:1789-98.

123. Spitsin SV, Scott GS, Mikheeva T, Zborek A, Kean RB, Brimer CM, Koprowski $\mathrm{H}$, Hooper DC. Comparison of uric acid and ascorbic acid in protection against EAE. Free Radic Biol Med. 2002;33:1363-71.

124. Robinson SR, Dang TN, Dringen R, Bishop GM. Hemin toxicity: a preventable source of brain damage following hemorrhagic stroke. Redox Rep. 2009;14:228-35.

125. Xiong XY, Wang J, Qian ZM, Yang QW. Iron and intracerebral hemorrhage: from mechanism to translation. Transl Stroke Res. 2014;5:429-41.

126. Liu JS, Zhao ML, Brosnan CF, Lee SC. Expression of inducible nitric oxide synthase and nitrotyrosine in multiple sclerosis lesions. Am J Pathol. 2001;158:2057-66.

127. van Horssen J, Schreibelt G, Drexhage J, Hazes T, Dijkstra CD, van der Valk P, de Vries HE. Severe oxidative damage in multiple sclerosis lesions coincides with enhanced antioxidant enzyme expression. Free Radic Biol Med. 2008;45:1729-37.

128. Miljković D, Momčilović M, Stanojević Z, Rašić D, Mostarica-Stojković M. It is still not for the old iron: adjuvant effects of carbonyl iron in experimental autoimmune encephalomyelitis induction. J Neurochem. 2011;118:205-14.
129. LeVine SM. Oligodendrocytes and myelin sheaths in normal, quaking and shiverer brains are enriched in iron. J Neurosci Res. 1991;29:413-9.

130. Xie Y, Liu W, Zhang X, Wang L, Xu L, Xiong Y, Yang L, Sang H, Ye R, Liu X. Human Albumin Improves Long-Term Behavioral Sequelae After Subarachnoid Hemorrhage Through Neurovascular Remodeling. Crit Care Med. 2015:43:e440-9.

131. Bagasra O, Michaels FH, Zheng YM, Bobroski LE, Spitsin SV, Fu ZF, Tawadros $\mathrm{R}$, Koprowski $\mathrm{H}$. Activation of the inducible form of nitric oxide synthase in the brains of patients with multiple sclerosis. Proc Natl Acad Sci U S A. 1995;92:12041-5.

132. De Groot CJ, Ruuls SR, Theeuwes JW, Dijkstra CD, Van der Valk P. Immunocytochemical characterization of the expression of inducible and constitutive isoforms of nitric oxide synthase in demyelinating multiple sclerosis lesions. J Neuropathol Exp Neurol. 1997;56:10-20.

133. Nagra RM, Becher B, Tourtellotte WW, Antel JP, Gold D, Paladino T, Smith RA, Nelson JR, Reynolds WF. Immunohistochemical and genetic evidence of myeloperoxidase involvement in multiple sclerosis. J Neuroimmunol. 1997;78:97-107.

134. Tran EH, Hardin-Pouzet $H$, Verge $G$, Owens T. Astrocytes and microglia express inducible nitric oxide synthase in mice with experimental allergic encephalomyelitis. J Neuroimmunol. 1997:74:121-9.

135. Miller E, Wachowicz B, Majsterek I. Advances in antioxidative therapy of multiple sclerosis. Curr Med Chem. 2013;20:4720-30.

136. Raivich G, Banati R. Brain microglia and blood-derived macrophages: molecular profiles and functional roles in multiple sclerosis and animal models of autoimmune demyelinating disease. Brain Res Brain Res Rev. 2004:46:261-81.

137. Chen JW, Breckwoldt MO, Aikawa E, Chiang G, Weissleder R. Myeloperoxidase-targeted imaging of active inflammatory lesions in murine experimental autoimmune encephalomyelitis. Brain. 2008;131:1123-33.

138. Gray E, Thomas TL, Betmouni S, Scolding N, Love S. Elevated myeloperoxidase activity in white matter in multiple sclerosis. Neurosci Lett. 2008;444:195-8.

139. Forghani R, Wojtkiewicz GR, Zhang Y, Seeburg D, Bautz BR, Pulli B, Milewski AR, Atkinson WL, Iwamoto $Y$, Zhang ER, Etzrodt M, Rodriguez E, Robbins CS, Swirski FK, Weissleder R, Chen JW. Demyelinating diseases: myeloperoxidase as an imaging biomarker and therapeutic target. Radiology. 2012;263:451-60.

140. Salavej P, Spalteholz H, Arnhold J. Modification of amino acid residues in human serum albumin by myeloperoxidase. Free Radic Biol Med. 2006;40:516-25

141. Bruschi M, Santucci L, Candiano G, Ghiggeri GM. Albumin heterogeneity in low-abundance fluids. The case of urine and cerebro-spinal fluid. Biochim Biophys Acta. 1830;2013:5503-8.

142. D’Aguanno S, Franciotta D, Lupisella S, Barassi A, Pieragostino D, Lugaresi A, Centonze D, D'Eril GM, Bernardini S, Federici G, Urbani A. Protein profiling of Guillain-Barrè syndrome cerebrospinal fluid by two-dimensional electrophoresis and mass spectrometry. Neurosci Lett. 2010;485:49-54.

143. Roy D, Quiles J, Gaze DC, Collinson P, Kaski JC, Baxter GF. Role of reactive oxygen species on the formation of the novel diagnostic marker ischaemia modified albumin. Heart. 2006;92:113-4.

144. Aydin O, Ellidag HY, Eren E, Kurtulus F, Yaman A, Yılmaz N. Ischemia modified albumin is an indicator of oxidative stress in multiple sclerosis. Biochem Med (Zagreb). 2014;24:383-9.

145. den Heijer T, Vermeer SE, Clarke R, Oudkerk M, Koudstaal PJ, Hofman A Breteler MM. Homocysteine and brain atrophy on MRI of non-demented elderly. Brain. 2003;126:170-5.

146. Obeid R, Herrmann W. Mechanisms of homocysteine neurotoxicity in neurodegenerative diseases with special reference to dementia. FEBS Lett. 2006;580:2994-3005.

147. Di Giuseppe D, Ulivelli M, Bartalini S, Battistini S, Cerase A, Passero S, Summa D, Frosali S, Priora R, Margaritis A, Di Simplicio P. Regulation of redox forms of plasma thiols by albumin in multiple sclerosis after fasting and methionine loading test. Amino Acids. 2010;38:1461-71.

148. Zoccolella S, Tortorella C, laffaldano P, Direnzo V, D'Onghia M, Paolicelli D, Livrea $\mathrm{P}$, Trojano M. Elevated plasma homocysteine levels in patients with multiple sclerosis are associated with male gender. J Neurol. 2012:259:2105-10.

149. Ramsaransing GS, Fokkema MR, Teelken A, Arutjunyan AV, Koch M, De Keyser J. Plasma homocysteine levels in multiple sclerosis. J Neurol Neurosurg Psychiatry. 2006;77:189-92. 
150. Sengupta S, Chen H, Togawa T, DiBello PM, Majors AK, Büdy B, Ketterer ME, Jacobsen DW. Albumin thiolate anion is an intermediate in the formation of albumin-S-S-homocysteine. J Biol Chem. 2001;276:30111-7.

151. Summa D, Spiga O, Bernini A, Venditti V, Priora R, Frosali S, Margaritis A, Di Giuseppe D, Niccolai N, Di Simplicio P. Protein-thiol substitution or protein dethiolation by thiol/disulfide exchange reactions: the albumin model. Proteins. 2007;69:369-78

152. Ahn SM, Byun K, Cho K, Kim JY, Yoo JS, Kim D, Paek SH, Kim SU, Simpson RJ, Lee B. Human microglial cells synthesize albumin in brain. PLoS One. 2008:3:e2829.

153. Prajapati KD, Sharma SS, Roy N. Upregulation of albumin expression in focal ischemic rat brain. Brain Res. 2010;1327:118-24.

154. Prajapati KD, Sharma SS, Roy N. Hepatocyte nuclear factor-1alpha mediated upregulation of albumin expression in focal ischemic rat brain. Neurol Res. 2012;34:25-31.

155. Byun K, Bayarsaikhan E, Kim D, Kim CY, Mook-Jung I, Paek SH, Kim SU, Yamamoto T, Won MH, Song BJ, Park YM. Lee Induction of neuronal death by microglial AGE-albumin: implications for Alzheimer's disease. PLoS One. 2012; 7:e37917.

156. Byun K, Bayarsaikhan D, Bayarsaikhan E, Son M, Oh S, Lee J, Son HI, Won MH, Kim SU, Song BJ, Lee B. Microglial AGE-albumin is critical in promoting alcohol-induced neurodegeneration in rats and humans. PLoS One. 2014;9:e104699.

157. Sternberg Z, Ostrow $P$, Vaughan M, Chichelli T, Munschauer F. AGE-RAGE in multiple sclerosis brain. Immunol Invest. 2011;40:197-205.

158. Sternberg Z, Hennies C, Sternberg D, Bistulfi GL, Kazim L, Benedict RH, Chadha K, Leung C, Weinstock-Guttman B, Munschauer F. Plasma pentosidine: a potential biomarker in the management of multiple sclerosis. Mult Scler. 2011;17:157-63.

159. Sakata N, Moh A, Takebayashi S. Contribution of superoxide to reduced antioxidant activity of glycoxidative serum albumin. Heart Vessels. 2002;17:22-9.

160. Van Campenhout A, Van Campenhout C, Lagrou AR, Moorkens G, De Block C, Manuel-y-Keenoy B. Iron-binding antioxidant capacity is impaired in diabetes mellitus. Free Radic Biol Med. 2006;40:1749-55.

161. Faure P, Wiernsperger N, Polge C, Favier A, Halimi S. Impairment of the antioxidant properties of serum albumin in patients with diabetes: protective effects of metformin. Clin Sci (Lond). 2008;114:251-6.

162. Liu W, Xu GZ, Jiang CH, Tian J. Macrophage colony-stimulating factor and its receptor signaling augment glycated albumin-induced retinal microglial inflammation in vitro. BMC Cell Biol. 2011;12:5.

163. Reder AT, Genç K, Byskosh PV, Porrini AM. Monocyte activation in multiple sclerosis. Mult Scler. 1998;4:162-8.

164. Claudio L, Martiney JA, Brosnan CF. Ultrastructural studies of the bloodretina barrier after exposure to interleukin-1 beta or tumor necrosis factoralpha. Lab Invest. 1994;70:850-61.

165. Prajapati KD, Sharma SS, Roy N. Current perspectives on potential role of albumin in neuroprotection. Rev Neurosci. 2011;22:355-63.

166. Piazza O, Scarpati G. Endogenous agents that contribute to generate or prevent ischemic damage. In: Maurizio B, editor. Advances in the Preclinical Study of Ischemic Stroke. Dr. Maurizio Balestrino (Ed.), ISBN: 978-953-510290-8, InTech, Available from: http://www.intechopen.com/books/ advances-in-the-preclinicalstudy-of-ischemic-stroke/endogenousneuroprotective-compounds-in-stroke; 2012. Access 6 Apr 2016.

167. Bento-Abreu A, Velasco A, Polo-Hernández E, Pérez-Reyes PL, Tabernero A, Medina JM. Megalin is a receptor for albumin in astrocytes and is required for the synthesis of the neurotrophic factor oleic acid. Neurochem. 2008;106:1149-59.

168. Tabernero A, Lavado EM, Granda B, Velasco A, Medina JM. Neuronal differentiation is triggered by oleic acid synthesized and released by astrocytes. J Neurochem. 2001;79:606-16.

169. Tabernero A, Velasco A, Granda B, Lavado EM, Medina JM. Transcytosis of albumin in astrocytes activates the sterol regulatory element-binding protein-1, which promotes the synthesis of the neurotrophic factor oleic acid. J Biol Chem. 2002;277:4240-6.

170. Hamilton JA, Era S, Bhamidipati SP, Reed RG. Locations of the three primary binding sites for long-chain fatty acids on bovine serum albumin. Proc Natl Acad Sci U S A. 1991;88:2051-4

171. Cain LD, Nie L, Hughes MG, Johnson K, Echetebu C, Xu GY, Hulsebosch CE, McAdoo DJ. Serum albumin improves recovery from spinal cord injury. J Neurosci Res. 2007;85:1558-67.
172. Avila-Martin G, Galan-Arriero I, Gómez-Soriano J, Taylor J. Treatment of rat spinal cord injury with the neurotrophic factor albumin-oleic acid: translational application for paralysis, spasticity and pain. PLoS One. 2011;6:e26107.

173. Chang TS, Jensen MB. Haemodilution for acute ischaemic stroke. Cochrane Database Syst Rev. 2014:8:CD000103.

174. Ginsberg MD, Palesch YY, Martin RH, Hill MD, Moy CS, Waldman BD, Yeatts $\mathrm{SD}$, Tamariz D, Ryckborst K. The albumin in acute stroke (ALIAS) multicenter clinical trial: safety analysis of part 1 and rationale and design of part 2. Stroke. 2011;42:119-27.

175. Christiansen CF. Risk of vascular disease in patients with multiple sclerosis: a review. Neurol Res. 2012;34:746-53.

176. Hassel B, Iversen EG, Fonnum F. Neurotoxicity of albumin in vivo. Neurosci Lett. 1994;167:29-32.

177. Kadota E, Nonaka K, Karasuno M, Nishi K, Teramura K, Hashimoto S. Neurotoxicity of serum components, comparison between CA1 and striatum. Acta Neurochir Suppl. 1997;70:141-3.

178. Chen ZL, Indyk JA, Bugge TH, Kombrinck KW, Degen JL, Strickland S. Neuronal death and blood-brain barrier breakdown after excitotoxic injury are independent processes. J Neurosci. 1999;19:9813-20.

179. Frigerio F, Frasca A, Weissberg I, Parrella S, Friedman A, Vezzani A, Noé FM. Long-lasting pro-ictogenic effects induced in vivo by rat brain exposure to serum albumin in the absence of concomitant pathology. Epilepsia. 2012;53:1887-97.

180. Ralay Ranaivo H, Wainwright MS. Albumin activates astrocytes and microglia through mitogen-activated protein kinase pathways. Brain Res. 2010;1313:222-31

181. Rossi S, Furlan R, De Chiara V, Motta C, Studer V, Mori F, Musella A, Bergami A, Muzio L, Bernardi G, Battistini L, Martino G, Centonze D. Interleukin-1ß causes synaptic hyperexcitability in multiple sclerosis. Ann Neurol. 2012;71:76-83.

182. Blauth K, Zhang X, Chopra M, Rogan S, Markovic-Plese S. The role of fractalkine (CX3CL1) in regulation of CD4(+) cell migration to the central nervous system in patients with relapsing-remitting multiple sclerosis. Clin Immunol. 2015;157:121-32.

183. Hooper C, Taylor DL, Pocock JM. Pure albumin is a potent trigger of calcium signalling and proliferation in microglia but not macrophages or astrocytes. J Neurochem. 2005;92:1363-76.

184. Marrie RA, Reider N, Cohen J, Trojano M, Sorensen PS, Cutter G, Reingold S, Stuve O. A systematic review of the incidence and prevalence of sleep disorders and seizure disorders in multiple sclerosis. Mult Scler. 2015;21:342-9.

185. Tomkins O, Friedman O, Ivens S, Reiffurth C, Major S, Dreier JP, Heinemann $\mathrm{U}$, Friedman A. Blood-brain barrier disruption results in delayed functional and structural alterations in the rat neocortex. Neurobiol Dis. 2007;25:367-77.

186. Vega-Zelaya L, Ortega GJ, Sola RG, Pastor J. Plasma albumin induces cytosolic calcium oscilations and DNA synthesis in human cultured astrocytes. Biomed Res Int. 2014:2014:539140.

187. David Y, Cacheaux LP, Ivens S, Lapilover E, Heinemann U, Kaufer D, Friedman A. Astrocytic dysfunction in epileptogenesis: consequence of altered potassium and glutamate homeostasis? J Neurosci. 2009:29:10588-99.

188. Tabernero A, Granda B, Medina A, Sánchez-Abarca LI, Lavado E, Medina JM. Albumin promotes neuronal survival by increasing the synthesis and release of glutamate. J Neurochem. 2002;81:881-91.

189. Stojanovic IR, Kostic M, Ljubisavljevic S. The role of glutamate and its receptors in multiple sclerosis. J Neural Transm (Vienna). 2014;121: 945-55.

190. Higashi K, Fujita A, Inanobe A, Tanemoto M, Doi K, Kubo T, Kurachi Y. An inwardly rectifying $K(+)$ channel, Kir4.1, expressed in astrocytes surrounds synapses and blood vessels in brain. Am J Physiol Cell Physiol. 2001;281:C922-31.

191. Schirmer L, Srivastava R, Kalluri SR, Böttinger S, Herwerth M, Carassiti D, Srivastava B, Gempt J, Schlegel J, Kuhlmann T, Korn T, Reynolds R, Hemmer B. Differential loss of KIR4.1 immunoreactivity in multiple sclerosis lesions. Ann Neurol. 2014;75:810-28.

192. Srivastava R, Aslam M, Kalluri SR, Schirmer L, Buck D, Tackenberg B, Rothhammer V, Chan A, Gold R, Berthele A, Bennett JL, Korn T, Hemmer B. Potassium channel KIR4.1 as an immune target in multiple sclerosis. N Engl J Med. 2012;367:115-23. 
193. Brill L, Goldberg L, Karni A, Petrou P, Abramsky O, Ovadia H, Ben-Hur T, Karussis D, Vaknin-Dembinsky A. Increased anti-KIR4.1 antibodies in multiple sclerosis: could it be a marker of disease relapse? Mult Scler. 2015;21:572-9.

194. Schneider R. Autoantibodies to Potassium Channel KIR4.1 in Multiple Sclerosis. Front Neurol. 2013;4:125.

195. Brickshawana A, Hinson SR, Romero MF, Lucchinetti CF, Guo Y, Buttmann M, McKeon A, Pittock SJ, Chang MH, Chen AP, Kryzer TJ, Fryer JP, Jenkins SM, Cabre P, Lennon VA. Investigation of the KIR4.1 potassium channel as a putative antigen in patients with multiple sclerosis: a comparative study Lancet Neurol. 2014;13:795-806.

196. Wunsch M, Rovituso DM, Kuerten S. KIR4.1 Antibodies as Biomarkers in Multiple Sclerosis. Front Neurol. 2014;5:62.

Submit your next manuscript to BioMed Central and we will help you at every step:

- We accept pre-submission inquiries

- Our selector tool helps you to find the most relevant journal

- We provide round the clock customer support

- Convenient online submission

- Thorough peer review

- Inclusion in PubMed and all major indexing services

- Maximum visibility for your research

Submit your manuscript at www.biomedcentral.com/submit
Biomed Central 